\title{
Validity and Reliability of The Authentic Happiness Scale
}

\author{
Esat Sanli ${ }^{*}$, Seher Balci Celik ${ }^{2}$, Cem Gencoglu ${ }^{3}$ \\ ${ }^{1}$ Faculty of Education, Department of Educational Sciences, Ondokuz Mayis University \\ (OMU), Samsun, Turkey; ${ }^{2}$ Faculty of Education, Department of Educational Sciences, \\ Ondokuz Mayıs University (OMU), Samsun, Turkey; ${ }^{3}$ Ministry of Education, Ankara, \\ Turkey. \\ *Corresponding author: esat.sanli@omu.edu.tr
}

\begin{abstract}
Studies on the concept of happiness have led to questions about whether all symptoms of happiness correspond to a real and healthy emotional state. Therefore, in this research, a scale was developed to examine the concept of "authentic happiness" coined by Seligman. Firstly, literature that explains authentic happiness and defines its relationship to other psychological concepts was reviewed, and then a theoretical framework was developed based on this information and the psychometric characteristics of the scale were introduced. The results of the confirmatory factor analysis revealed that the fit indices were compatible with twodimensional structure. These two dimensions have been entitled as "Authentic Happiness" and "Fluctuating Happiness". Based on the findings of the present study, the Authentic Happiness Scale (AHS) is a reliable and valid scale to determine the authentic happiness levels of university students.
\end{abstract}

Keywords: happiness, authentic happiness, fluctuating happiness, authenticity.

\section{Introduction}

Studies conducted in psychology have long focused on concepts such as depression, anxiety, or personality disorders (Doğan \& Akıncı Çötok, 2011, p. 165), leaving positive emotions and dispositions in the background. Focusing on negative emotions and dispositions is not a simple preference, rather it is based on the fact that the measurement of positive emotions is more difficult when compared to negative ones. Emotions are subjective and cannot be observed directly and measured by others. They become measurable and observable only when they are expressed through behaviors. As the aim of scientific research is to test explanations of observable phenomena (An1l \& Güler, 2006, p. 30), it is much easier to study negative emotions as their behavioral reflections are more clearly visible. On the 
other hand, it is a more difficult process to identify positive emotions due to the vagueness of the visible behaviors that reflect such emotions (Seligman, 2004, p. $32)$.

However, it is not impossible to conduct tangible research on positive emotions. Folkman (2008) points out that most of the literature covers negative emotions and stresses that research should also focus on how positive emotions emerge and are maintained, and what kinds of social and psychological consequences they may trigger. With the expansion of the understanding stressed by Folkman, there has been a shift from the study of negative emotions to positive ones, especially since the 1980s (Toner, Haslam, Robinson, \& Williams, 2012, p. 637). Researchers have started to examine notions such as happiness, life satisfaction, optimism, and wellbeing, and to investigate their reflections in a variety of populations and contexts. With this in mind, the concept of happiness is particularly important among the notions investigated since other concepts, such as optimism and well-being, are related to happiness.

Despite several attempts to define happiness and its sub-dimensions, as with other abstract concepts, there is no commonly agreed upon definition of happiness (Bognar, 2010, p. 272). However, it is important to reach a general definition of the concept based on common points in order to study it. According to Seligman (2011), happiness refers to the signs of cognitive evaluations indicating that an individual takes the right path in the life game, the consistent and persistent pursuit of meaning and purpose, and the fact that positive emotions are experienced more often than negative ones. Sapmaz and Doğan (2012, p. 63) point out that there are three elements commonly at the fore in definitions of happiness. The first is the frequency of experiencing positive emotions, the second is the frequency of experiencing negative emotions, and the last is life satisfaction. It should also be emphasized that emotional experiences do not progress from good to bad moods or from happiness to sadness in a one-dimensional way, rather they develop along with motivations, coping strategies, basic positive and negative emotions, and sensitivity toward them (Gencoğlu \& Y1lmaz, 2013, p. 964). Hence, the components of happiness are not part of a hierarchical structure of emotions but rather a process. Furthermore, the proportion of negative emotions might play a role in strengthening personality (Tarhan, 2009, p. 193). Emotions initially labelled as negative when they are first experienced can become positive later. Thus, permanent happiness could be gained not only by experiencing positive emotions, but also by converting negative experiences into positive ones.

Research on happiness has posed the question of whether all signs of happiness are real and healthy indicators of happiness. Seligman (2002) tried to define happiness 
with a new concept, "authentic happiness," to fill the significant gap in the definitions in the literature. Authenticity means that individuals are honest and realistic and express themselves in sincere ways (Peterson, Park, \& Seligman, 2006). In other words, authenticity is the way individuals portray themselves as honest and realistic both to themselves and others (Turan, 2013, p. 79). Therefore, the definition of authentic happiness is the more stable emotional state that is built on an individual's internalized values and meanings about life (Headeyab et al., 2010). Authentic happiness implies a righteous lifestyle (Martin, 2007, p. 89) and distinguishes hedonistic momentary pleasures from healthy positive emotions. This combination of authenticity and happiness is not arbitrary; it is grounded in a consistent and sensible philosophical background. Seligman and Royzman (2003) state that authentic happiness is the outcome of three types of traditional theories of happiness: hedonism theory, desire theory, and objective list theory. Hedonism theory refers to the rapid and inevitable adaptation to the good by taking them for granted through the seeking of maximum pleasure and minimal pain. According to the theory of desire, happiness depends on what is an individual desire. The situations that bring happiness to each individual are quite different. Each individual should do what $\mathrm{s} /$ he wants in order to achieve happiness according to this approach. Objective list theory takes the view that happiness is the result of the efforts and distinctive purposes of individuals which are uniquely meaningful and satisfactory. According to this approach, the individual will be happy as long as they define personal and vital goals. In this respect, authentic happiness is the synthesis of a pleasurable experience from the perspective of hedonism theory, well-being from the perspective of desire theory, and meaningful life from the perspective of objective list theory (Peterson et al., 2007). In this study, the Authentic Happiness Scale (AHS) assesses the happiness that the theory of intention lists, while desire and desire theory are in the background. The dimension of unstable happiness, on the other hand, sees hedonism as the center of happiness and desire, which does not take into account the theory of goals list. Therefore, in order to evaluate authentic happiness, it is not enough to examine goals and targets alone. Determining how close a person is to authentic happiness and how far away from unstable happiness will strengthen the end results.

Despite having a similar basis, there are many different definitions and proposed sub-categories of authentic happiness. Dambrun and Ricard (2011) proposed the concept of fluctuating and authentic-durable happiness. Fluctuating happiness is the result of actions trying to maximize pleasures and to avoid displeasures through a self-centered functioning perspective where the phases of pleasure and displeasure alternate repeatedly. In contrast, authentic-durable happiness is the result of a selfless psychological functioning requiring the existence of an emotional state that is less dependent upon circumstances and more related to a person's own strengths and 
abilities to deal with whatever life brings (Seligman, 2002; Martin, 2007). Dambrun et al. (2012) developed a scale consisting of 23 items to measure these two types of happiness: 10 items of the scale are related to the dimension of Subjective Fluctuating Happiness (SFHS) and 13 items deal with the dimension of Subjective Authentic-Durable Happiness (SA-DHS). The scale developed in this study has similar primary objectives to that created by Dambrun et al. (2012); however, in their scale, authentic happiness is measured by scoring words, while in this study, the items created as attitude cues are measured.

Additionally, there are many other scales developed to measure happiness in the literature. Peterson and Park (2008, as cited in Park, Park, \& Peterson, 2010), developed the Authentic Happiness Inventory consisting of 24 items with five options representing the degrees of happiness. Higher scores indicate a higher level of authentic happiness. The Cronbach's alpha coefficient of this scale is .95 .

The Oxford Happiness Inventory (OHI) developed by Martin and Crossland (1989) is among the scales frequently used to determine happiness. This four-point Likerttype scale (0-3) consisting of 29 items was later revised by Hills and Argyle (2002). As a result of this revision, the Oxford Happiness Questionnaire (OHQ) and an eightitem short-form version were produced. The revised scale is a six-point Likert-type scale with an internal consistency coefficient of .92. The short-form version of the OHQ was later adapted into Turkish by Doğan and Akıncı Çötok (2011). The internal consistency and test-retest reliability coefficients of the Turkish version are .92 and .85 , respectively.

All in all, it would be misleading to measure and evaluate happiness alone because it is difficult to discern healthy happiness from a state of happiness that emerges in an unstable lifestyle lacking responsibility. Thus, the development and use of scales that address happiness together with its healthy and unhealthy aspects should improve the quality of research and studies on happiness. The aim of this research is to develop a reliable and valid measurement tool with the desired psychometric characteristics to objectively assess individuals' levels of both authentic and fluctuating happiness.

\section{Methodology}

\section{Population}

For the development of the Authentic Happiness Scale, data was collected from students studying at Ondokuz Mayis University during the 2013-2014 academic 
year. For the exploratory factor analysis, the first study group was composed of 248 students (188 women, 60 men) studying in the Faculty of Education and Faculty of Science and Letters. For the confirmatory factor analysis, the second study group was composed of 477 students (283 women, 184 men) studying in the Faculty of Education, Faculty of Theology, College of Health, and College of Physical Education and Sports. The average age of the participants was 20,87. Informed consent was obtained from all individual participants included in the study.

\section{Data Collection Tools}

Authenticity Scale: The scale was developed by Wood et al. (2008) and adapted into Turkish by İlhan and Özdemir (2013). The scale involves three four-item sub-scales: self-alienation, authentic living, and accepting external influence. It is a seven-point Likert-type scale composed of 12 items. The second factor analysis showed that all items loaded on a single factor, which enabled an evaluation by total points. The Cronbach's alpha internal consistency coefficient was found to be .78 for selfalienation, .78 for accepting external influence, and .69 for authentic living. The testretest reliability was assessed with a two- or four-week interval and the reliability coefficient varied from .85 to .91 .

\section{Scale Development Process}

First, a comprehensive literature review was conducted, related theses and accessible articles were examined, and a coherent and logical definition was accordingly proposed. Second, senior students in the department of Turkish Language Teaching were asked to write essays on this topic in line with the proposed definition. Based on the literature review and written essays, a pool of 51 items was created. As expert opinion is a method to ensure objective content validity (Y1lmaz, 1999), eight academicians holding at least a doctoral degree and working in the Department of Psychology and Counselling were asked for their opinion on the content validity of the first form consisting of 51 items.

Content validity ratios (CVR) were developed in order to objectively evaluate the views of experts (Lawshe, 1975; Yurdugül, 2005, p. 2). According to Lawshe's method, there should be at least five experts. CVRs are calculated based on the number of experts saying "necessary" minus 1 . If half the experts say "necessary," the ratio will be 0 , if there are more experts saying necessary than not, the ratio will be CVR>0, and finally, if there are more experts saying unnecessary rather than necessary, the ratio will be $\mathrm{CVR}<0$. The items with $\mathrm{CVR}<0$ or $\mathrm{CVR}=0$ were the first ones eliminated. The items with a positive CVR were then statistically calculated for the purpose of testing their significance. While the statistical significance of CVRs was previously tested through cumulative normal distribution tables, the minimum 
values (content validity criteria) with $\alpha=0.05$ significant levels were later converted into tables by Veneziano and Hooper (1997) for a more convenient analysis. Hence, the minimum values for the number of experts also show the statistical significance (Yurdugül, 2005, p. 2). The expert views were evaluated in terms of Lawshe's method, and 14 items were eliminated from the scale. The remaining 37 items were converted into a five-point Likert-type scale. Finally, this scale was administered to 251 students studying in different departments of Ondokuz Mayıs University.

\section{Data Analysis}

In the first part of this study, reliability and validity analyses were performed. For exploratory factor analysis, it is recommended that at least five people be applied to each item (Büyüköztürk, 2002) . Stevens (2009) notes that a sample of 200 people is usually sufficient to derive reliable factors. To meet both of these criteria, the scale was administered to 251 individuals. Three of the participants were excluded because of the incompleteness of the data; therefore, the data obtained from 248 students was analyzed. SPSS 21 software was used for the exploratory factor analysis (EFA). The Cronbach's alpha coefficient was considered for the reliability analysis. Lastly, after the EFA, the validity of the structure was tested through confirmatory factor analysis (CFA) on AMOS 20 software.

\section{Results}

The results of the validity and reliability analyses of the Authentic Happiness Scale are presented below.

\section{Validity Results}

Factor analysis is a method in which observed data values are expressed as functions of a number of possible causes in order to ascertain which causes are the most significant. There are two types of factor analysis: exploratory factor analysis aims to group factors with correlations among items, whereas confirmatory factor analysis tests a hypothesis or conjecture for the relationship between variables (Büyüköztürk, 2011, p. 123).

The data obtained from 248 students was used for the exploratory factor analysis. The Kaiser-Meyer-Olkin (KMO) test and Bartlett Sphericity test were used to test the suitability of the data for the factor analysis. The data was proven to be suitable 
for the factor analysis as the KMO value was found to be .860 and the Barlett Sphericity test value was .000 (Büyüköztürk, 2011; Kalayc1, 2010).

The exploratory factor analysis was conducted through the Varimax method by considering the criteria that the eigenvalues of each factor should be less than 1 and should have a minimum value of .40, especially when the number of participants is at least 200 (Kim-Yin, 2004; as cited in Şencan, 2005). Ten items were eliminated from the scale because they had factor loading of less than .40 or loading differences for different factors were 10 or below according to the Rotated Factor Matrix Table. Based on the final analysis, the factor loadings of 16 items were found to group into two factors. The distribution of the factor loadings is presented in Table 1.

\section{Table 1:}

Distribution of Factor Loadings

\begin{tabular}{|c|c|c|c|c|}
\hline & Scale Item & EFA* & $\begin{array}{c}\text { CFA } \\
* *\end{array}$ & $\begin{array}{l}\text { Item-Total } \\
\text { Score } \\
\text { Correlation }\end{array}$ \\
\hline & \multicolumn{4}{|l|}{ Authentic Happiness } \\
\hline 1 & $\begin{array}{l}\text { I am avare of the meaning of my life. } \\
\text { Hayatımın anlamintn farkindayım. }\end{array}$ & .529 & .556 & .633 \\
\hline 5 & $\begin{array}{l}\text { The people around me make me happy. } \\
\text { Çevremdeki insanlarm varlığt beni mutlu ediyor. }\end{array}$ & .570 & .503 & .605 \\
\hline 6 & $\begin{array}{l}\text { Some of my feelings cause me pain, but I think they have helped me grow } \\
\text { as a person. } \\
\text { Bazı duygulartm bana act verse de onların beni gelisstirdiğini } \\
\text { düsünüyorum. }\end{array}$ & .742 & .481 & .663 \\
\hline 8 & $\begin{array}{l}\text { Every new day means new hope for me. } \\
\text { Benim için başlayan her yeni gün yeni bir umut demek. }\end{array}$ & .655 & .697 & .694 \\
\hline 9 & $\begin{array}{l}\text { I believe that all pain adds something positive to my life. } \\
\text { Her acımın bana olumlu bir seyler kattığına inantrm. }\end{array}$ & .853 & .569 & .698 \\
\hline 15 & $\begin{array}{l}\text { The fact that my life has meaning makes me happy. } \\
\text { Hayatimdaki anlam beni mutlu ediyor. }\end{array}$ & .489 & .628 & .655 \\
\hline \multirow[t]{2}{*}{18} & $\begin{array}{l}\text { When I'm sad, I feel comforted by thinking what I have. } \\
\text { Uzzüldüğ̈ümde, sahip olduklarmı düssünerek teselli olurum. }\end{array}$ & .779 & .457 & .594 \\
\hline & Fluctuating Happiness & & & \\
\hline 2 & $\begin{array}{l}\text { Life is not going as I want. } \\
\text { Hayat istedigim gibi gitmiyor. }\end{array}$ & .715 & .513 & .588 \\
\hline 3 & $\begin{array}{l}\text { I feel like I'm acting differently than I feel to look happy to other people. } \\
\text { İnsanlara mutlu görünmek için olduğumdan farklı davrandığımı } \\
\text { hissediyorum. }\end{array}$ & .654 & .563 & .635 \\
\hline 4 & $\begin{array}{l}\text { I am quite far away from happiness, except for daiy entertainments } \\
\text { Günlük eğlenceler dişında mutluluktan oldukça uzağım. }\end{array}$ & .661 & .660 & .713 \\
\hline 7 & $\begin{array}{l}\text { Nothing makes me happy easily. } \\
\text { Hiçbir şeyden kolay kolay mutlu olamtyorum. }\end{array}$ & .628 & .558 & .614 \\
\hline
\end{tabular}




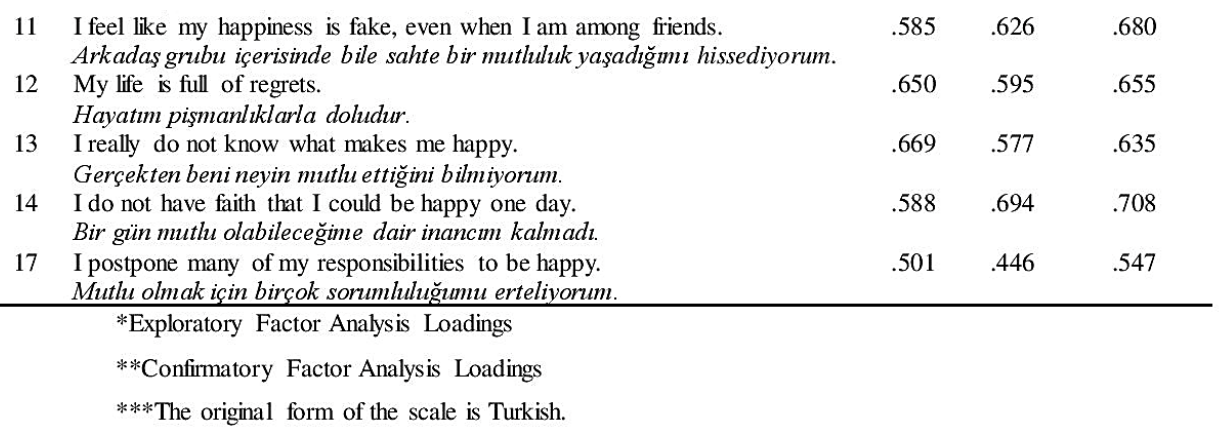

The distribution of the factors based on the exploratory factor analysis and their variances are given in Table 2 .

\section{Table 2:}

Distribution of the Factors Based on the Exploratory Factor Analysis and their Variances

\begin{tabular}{cccc}
\hline $\begin{array}{c}\text { Number of } \\
\text { Factors }\end{array}$ & Items & Factor Titles & $\begin{array}{c}\text { Explained } \\
\text { Variance }\end{array}$ \\
\hline $\mathbf{1}$ & $1,5,6,8,9,15,18$ & $\begin{array}{c}\text { Authentic } \\
\text { Happiness } \\
2\end{array}$ & $\begin{array}{c}\text { Fluctuating } \\
\text { Happiness }\end{array}$ \\
Total & 16 & 2 & $32.73 \%$ \\
\hline
\end{tabular}

As seen in Table 2, the explained variance of Factor 1 was $12.81 \%$, and the explained variance of Factor 2 was 32.73\%. The group of seven items under Factor 1 was labeled "Authentic-Durable Happiness" and the other group of nine items under Factor 2 was called "Fluctuating Happiness." The total explained variance of the entire scale consisting of 16 items was $45.54 \%$.

\section{Results of the Confirmatory Factor Analysis}

The confirmatory factor analysis was conducted using the SPSS Amos 20 program in order to test the construct validity of the two-factor scale. Data obtained from the 477 participants was used for the CFA testing of the 16-item Authentic Happiness Scale. Goodness of fit statistics were used to test whether this scale would be acceptable or not. 
The fit indices of Model 1 based on the first analysis are provided in Table 3. Amos 20 suggested a modification to items " 6 " and "9." This kind of modification can be done when item content is very similar (Byrne, 2009). Thus, the content of item 6: "Some of my feelings cause me pain, but I think they have helped me grow as a person." and item 9: "I believe that all pain adds something positive to my life." were considered to be similar and thus able to be modified. The error covariance of these two items was included in the model for modification, and the analysis was repeated. The fit indices of the second analysis are presented as Model 2 in Table 3. The modification was considered to be sufficient in terms of the goodness of fit indices and the values of Model 2 were accepted as the values of the confirmatory factor analysis. The CFA revealed that there was no item that had high error variances and low statistical significance $(t)$ values. Goodness of fit scores for the CFA are presented in Table 3.

Table 3:

CFA Goodness of Fit Scores for the Two Models

\begin{tabular}{cccccc}
\hline Model & $\mathbf{x}^{2} / \mathbf{s d}$ & GFI & AGFI & CFI & RMSEA \\
\hline Model 1 & 2.816 & .929 & .906 & .90 & .062 \\
Model 2 & 2.505 & .938 & .917 & .92 & .056 \\
\hline
\end{tabular}

As seen in Table 3, for $x^{2} / s d=2.505$, the value is below 3. This kind of value of $x^{2} / \mathrm{sd}$ corresponds to perfect fit for larger sample groups (Kline, 2005, p. 136, as cited in Çokluk, Şekercioğlu, \& Büyüköztürk, 2012). The ideal values of GFI, AGFI, and CFI should be greater than .90. The RMR value should be less than .05 and RMSEA less than 0.08. If the values of RMSEA, RMR, and sRMR are less than 0.05, it corresponds to perfect fit; if they are between 0.05 and 0.08 , it corresponds to good fit; and values varying from 0.08 to 0.10 correspond to poor fit. If the values of GFI, AGFI, NNFI, and CFI are 0.95 or above, it corresponds to perfect fit, if the values are between 0.90 and 0.95 , it corresponds to good fit (Çokluk, Şekercioğlu, \& Büyüköztürk, 2012). As seen in Table 3, all the values of the goodness of fit indices are at acceptable levels. However, the values of Model 2 are much closer to the ideal. Thus, the values of Model 2 are taken as the basis for the present study.

The goodness of fit indices are compatible with the results of the exploratory factor analysis. The path schema derived from the confirmatory factor analysis is presented below. As seen in Figure 1, the factor loadings of all items are higher than 0.3, which corresponds to good fit for this two-factor scale. CFA results also showed that there 
was an intermediate level negative correlation between authentic-durable happiness and fluctuating happiness factors $(r=-.55, p<.001)$.

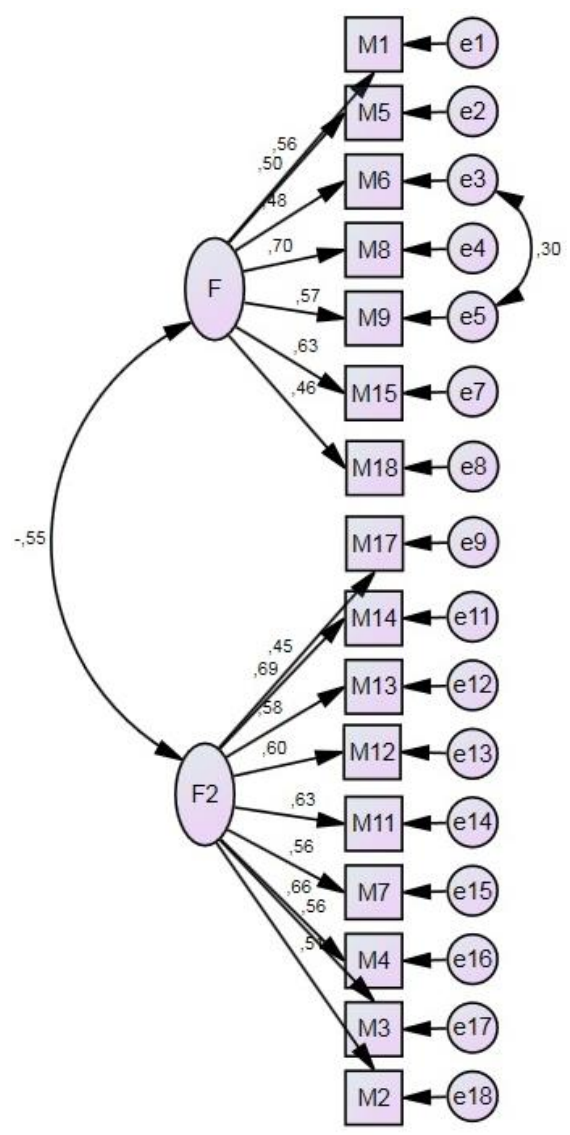

Figure 1. CFA path schema

\section{Criterion-Related Validity}

The Authenticity Scale developed by Wood et al. (2008) and adapted into Turkish by İlhan and Özdemir (2013) was used for the analysis of criterion-related validity. This scale has three subscales (self-alienation, authentic living, and accepting external influence) each of which has four sub-items. The internal consistency coefficient of the authentic living subscale was .62, the internal consistency coefficient of the self-alienation subscale was .67, and the internal consistency coefficient of the accepting external influence subscale was .79. The authentic happiness subscale has a positive correlation with the authentic living subscale and 
a negative correlation with the self-alienation subscale. The fluctuating happiness subscale has a negative correlation with the authentic living subscale and a positive correlation with the self-alienation subscale. The accepting external influence subscale was excluded from the analysis because of the different aims of the two measurement tools.

\section{Table 4:}

The Results of Criterion-Related Validity

\begin{tabular}{ccccc}
\hline $\begin{array}{c}\text { Pearson } \\
\text { Corelation }\end{array}$ & $\begin{array}{c}\text { Authentic } \\
\text { Happiness }\end{array}$ & $\begin{array}{c}\text { Fluctuating } \\
\text { Happiness }\end{array}$ & $\begin{array}{c}\text { Authentic } \\
\text { Living }\end{array}$ & $\begin{array}{c}\text { Self- } \\
\text { Alienation }\end{array}$ \\
\hline $\begin{array}{c}\text { Authentic } \\
\text { Happiness }\end{array}$ & 1 & $-.392^{* *}$ & $.388^{* *}$ & $-.175^{* *}$ \\
$\begin{array}{c}\text { Fluctuating } \\
\text { Happiness }\end{array}$ & 1 & $-.188^{* *}$ & $.447^{* *}$ \\
$\begin{array}{c}\text { Authentic } \\
\text { Living }\end{array}$ & & & 1 & $-.248^{* *}$ \\
$\begin{array}{c}\text { Self- } \\
\text { Alienation }\end{array}$ & & & & 1 \\
$\mathbf{N}$ & 478 & 478 & 478 & 478 \\
\hline $\mathbf{P}<.001^{* *}$ & & & & \\
& & & & \\
\end{tabular}

As seen in Table 4, in line with expectations, there was a positive correlation between authentic happiness and authentic living; a negative correlation between fluctuating happiness and authentic living; and a positive correlation between fluctuating happiness and self-alienation.

\section{Reliability Results}

\section{Item-Total Score Correlation}

Item-total score correlation is a method of reliability analysis. This method reveals the relationship between each item score and the total score of the test. Items with an item-total score correlation higher than .30 are considered reliable and valid, items with an item-total score correlation between .20 and .30 can be modified and re-included in the scale, but it would be better to exclude them from the scale, and 
items with an item-total score correlation less than .20 should be removed from the scale (Büyüköztürk, 2011, p. 171). In this study, after the item-total score correlation was tested, 11 items with an item-total score correlation less than .30 were excluded from the scale. In the end, there were 26 items left in the scale. In addition to the EFA, Cronbach's alpha internal consistency coefficients were also computed in order to test the reliability of the AHS. The reliability analysis was done both for the first group of participants consisting of 248 individuals and the second population consisting of 477 individuals. The internal consistency coefficients of the subscales are given in Table 5 .

Table 5:

Internal Consistency Coefficients of the Two Populations

\begin{tabular}{ccc}
\hline Sub-Scale & $\begin{array}{c}\text { First Population } \\
\text { Cronbach } \boldsymbol{\alpha}\end{array}$ & $\begin{array}{c}\text { Second Population } \\
\text { Cronbach } \boldsymbol{\alpha}\end{array}$ \\
\hline Authentic Happiness & .87 & .84 \\
Fluctuating Happiness & .88 & .87 \\
\hline
\end{tabular}

\section{Conclusion}

The aim of this study was to investigate the psychometric characteristics of the Authentic Happiness Scale in order to measure individuals' authentic happiness levels. The results of the analysis provided psychometric support that the 16-item, five-point Likert-type, two-factor AHS can be used as a two-dimensional scale. The ratio of total variance explained by the first factor was $12.81 \%$ and that explained by the second factor was $32.73 \%$. The seven items grouped into the first factor were labeled the Authentic Happiness Subscale, and the nine items grouped into the second factor were called the Fluctuating Happiness Subscale. The total variance explained by this 16 -item scale was $45.54 \%$.

Confirmatory factor analysis was used to determine whether this two-factor scale would show similar results in a different sample. The results of fit indices showed that the general structure of this scale was valid and compatible with what the theory and literature expected. Additionally, the scale has construct validity as the values were statistically significant, error variances were low, and factor loadings were high.

The lowest and highest scores that can be obtained from the Authentic Happiness Subscale are 7 and 35, and those from the Fluctuating Happiness Subscale are 9 and 
45. There are no reverse scoring items in the scale. A high score on the Authentic Happiness Subscale indicates a high propensity for authentic happiness while a high score from the Fluctuating Happiness Subscale indicates a high inclination towards fluctuating and momentary happiness. There is no general total score for the scale. The analysis results also showed that the scale has a high level of internal consistency.

\section{Discussion}

The results of the analysis provided psychometric support that the two-factor AHS can be used as a two-dimensional scale. Differentiation of factors was supported not only by statistical analysis but also by the literature. The Authentic Happiness Subscale includes such items as "Every new day means new hope for me." and "Some of my feelings cause me pain, but I think they have helped me grow as a person." Hence, the items in factor 1 were grouped under the title of Authentic Happiness. The concept of authentic happiness is defined as a consistent, spiritual, stable, harmonious, and responsible mood (Seligman, 2002; Martin, 2007; Headeyab et al., 2010). Individuals who are inclined to authentic happiness are unlikely to give up when they are confronted with obstacles and challenges. They seek out meaning and a source of happiness in their pain. They prefer to confront what they have experienced rather than rejecting or suppressing it. Hence, they are courageous and self-aware, which ensures that they remain consistent in their moods.

The Fluctuating Happiness Subscale includes such items as "I am quite far away from happiness, except for some moments during the day." and "I am postponing many of my responsibilities to be happy." Fluctuating happiness indicates an egocentric personality that seeks superficial pleasures and avoids any situation that might interfere with such pleasures (Dambrun et al., 2012). Therefore, there is no consistent and sustainable mood of happiness because the core element of this kind of happiness is pleasure. This kind of mood might conflict with individualistic, social, and universal values as it seeks pleasure in every experience. Such a conflict brings about regrets and defense mechanisms. Thus, this kind of happiness is fluctuating as it is dependent on the source of pleasure. Although such people seem to be happier than those who are inclined to show authentic happiness, they experience more regrets and sorrow because of the limitations of pleasures. For this reason, their mood is much more unstable, and thus such individuals fall into unhealthy fluctuating loops. With all these aspects in mind, the items grouped into two factors were compatible with the characteristics of those two moods as depicted in the literature. 
In summary, it is safe to say that the Authentic Happiness Scale is a valid and reliable measurement tool to determine the level of adults' authentic happiness.

\section{Implications, limitations, and future research directions}

- This scale was aimed primarily at late adolescents. Thus, the scale could be modified or adapted to those at different periods in their lives.

- Further studies could be conducted on adults in risk groups who are more likely to have high levels of fluctuating happiness according to the scale scores.

- In this study, happiness was evaluated only with authentic and fluctuating dimensions. Total score cannot be obtained from these two dimensions. It may be advisable to carry out studies that will enable the evaluation of happiness in different dimensions.

- When the results are evaluated in general, it can be said that the Authentic Happiness Scale is a valid and reliable measurement tool that can be used to measure authentic happiness tendencies of Turkish university students. However, these findings should be considered within the limitations. A possible limitation of the study is that the data are collected from students who continue their university education in Turkey. Thus, it is important that the Authentic Happiness Scale is supposed to be applied to elicit more evidence about the factor structure of the scale and the findings of this study.

\section{References}

Anıl, D., \& Güler, N. (2006). An example of the scaling study by pair-wise comparison method. Hacettepe University Journal of Education, 30, 30-36.

Argyle, M. M., \& Crossland, J. (1989). Happiness as a function of personality and social encounters. In J. P. Forgas, \& J. M. Innes (Eds.), Recent Advances in Social Psychology: An International Perspective (pp. 189-203). Amsterdam: North Holland: Elsevier Science.

Bognar, G. (2010). Authentic happiness. Utilitas, 22(3), 272-284. doi:10.1017/S0953820810000191

Büyüköztürk, Ş. (2011). Sosyal bilimler için veri analiz el kitabı [Data analysis handbook for social sciences]. Ankara: Pegem Akademi.

Büyüköztürk, Ş. (2002). Factor analysis: basic concepts and using to development scale. Educational Administration in Theory and Practice, 32, 470-483.

Byrne, B. (2009). Structural equation modeling with AMOS: Basic concepts, applications, and programming. New York: Routledge/Taylor \& Francis.

Çokluk, Ö., Şekercioğlu, G., \& Büyüköztürk, Ş. (2012). Sosyal bilimler için çok değişkenli istatistik SPSS ve LISREL uygulamalart[Multivariate statistical SPSS and LISREL applications for social sciences]. Ankara: Pegem Akademi. 
Dambrun, M., \& Ricard, M. (2011). Self-centeredness and selflessness: A theory of selfbased psychological functioning and its consequences for happiness. Review of General Psychology, 15(2), 138-157. doi.org/10.1037/a0023059

Dambrun, M., Rica, M., Després, G., Drelon, E., Gibelin, E., Gibelin, M., et al. (2012). Measuring happiness: From fluctuating happiness to authentic-durable happiness. Frontiers in Psychology (3), 1-11. doi:10.3389/fpsyg.2012.00016

Doğan, T., \& Akıncı Çötok, N. (2011). Adaptation of the short form of the Oxford Happiness Questionnaire into Turkish: A validity and reliability study. Turkish Psychological Counseling and Guidance Journal, 4(36), 165-172.

Dost, M. T. (2007). Examining life satisfaction levels of university students in terms of some variables. Pamukkale University Education Faculty Journal, 2(22), 132-143.

Folkman, S. (2008). The case for positive emotions in the process. Anxiety, Stress, \& Coping, 21(1), 3-14.

Gencoğlu, C., \& Y1lmaz, M. (2013). The effects of emotional awareness training program on the level of emotional control. International Journal of Social Science, 6(5), 961-980. doi.org/10.9761/JASSS1552.

Goleman, D. (2000). Duygusal zeka[Emotional intelligence]. (B. S. Yüksel, Trans.) İstanbul: Varlik Publications.

Headeyab, B., Schuppacd, J., Tucciae, I., \& Wagner, G. G. (2010). Authentic happiness theory supported by impact of religion on life satisfaction: A longitudinal analysis with data for Germany. The Journal of Positive Psychology, 5(1), 73-82.

Hills, P., \& Argyle, M. (2002). The Oxford Happiness Questionnaire: A compact scale for the measurement of psychological well-being. Personality and Individual Differences (33), 1073-1082.

İlhan, T., \& Özdemir, Y. (2013). Adaptation of authenticity scale to Turkish: A validity and reliability study. Turkish Psychological Counseling and Guidance Journal, 5(40), $142-153$.

Kalayc1, Ş. (2010). SPSS uygulamalı çok değişkenli istatistik teknikleri [SPSS applied multivariate statistical techniques] (5th ed.). Ankara: Asil Publication.

Martin, M. W. (2007). Happiness and virtue in positive psychology. Journal for the Theory of Social Behaviour, 37(1), 89-103.

Park, N., Park, M., \& Peterson, C. (2010). When is the search for meaning related to life satisfaction? Applied Psychology: Health and Well-Being, 2(1), 1-13. doi:10.1111/j.1758-0854.2009.01024.

Peterson, C., Park, N., \& Seligman, M. E. (2006). Greater strengths of character and recovery from illness. The Journal of Positive Psychology, 1(1), 17-26. doi.org/10.1080/17439760500372739

Peterson, C., Ruch, W., Beermann, U., Park, N., \& Seligman, M. E. (2007). Strengths of character, orientations to happiness, and life satisfaction. The Journal of Positive Psychology, 2(3), 149-156. doi.org/10.1080/17439760701228938

Pulkkinen, L., \& Kokko, K. (2000). Identity development in adulthood: A longitudinal study. Journal of Research in Personality, 34, 445-470. doi.org/10.1006/jrpe.2000.2296

Sapmaz, F., \& Doğan, T. (2012, December). Optimism as a predictor of happiness and life satisfaction. Mersin University Journal of the Faculty of Education, 8(3), 63-69. 
Seligman, M. E. (2002). Authentic happiness: Using the new positive psychology to realize your potential for lasting fulfillment. New York: Atria Paperback.

Seligman, M. E., \& Royzman, E. (2003). Happiness: The three traditional theories. Retrieved: October 10, 2014, from http://queksiewkhoon.tripod.com

Seligman, M. E. (2004). Authentic happiness: Using the new positive psychology to realize your potential for lasting fulfillment. Simon and Schuster.

Shepperd, J. A., Rothman, A. J., \& Klein, W. M. (2011). Self-regulation, identity-regulation and health. Self and Identity, 10(3), 281-283. doi.org/10.1080/15298868.2011.570426

Stevens, J. P. (2009). Applied multivariate statistics for the social science. New York: Routledge

Swart, J., \& Rothmann, S. (2012). Authentic happiness of managers, and individual and organisational outcomes. South African Journal of Psychology, 42(4), 492-508.

Tarhan, N. (2009). Duyguların dili[The language of feelings]. İstanbul: Timaş Publication.

Toner, E., Haslam, N., Robinson, J., \& Williams, P. (2012). Character strengths and wellbeing in adolescence: Structure and correlates of the values in action inventory of strengths for children. Personality and Individual Differences (52), 637-642. doi:10.1016/j.paid.2011.12.014

Turan, M. E. (2013). Otantiklik. In A. Akın, Current psychological concepts: Positive Psychology (pp. 79-89). İstanbul: Sakarya University Educational Sciences Institute Publications.

Wood, A. L. (2008). The authentic personality: A theoretical and empirical conceptualization and the development of the authenticity scale. Journal of Counseling Psychology (55), 385-399. doi:10.1037/0022-0167.55.3.385.

Yılmaz, A. (1999). Psikolojik değerlendirmenin temelleri [The bases of psychological evaluation]. Samsun: Etüt Publications.

Yurdugül, H. (2005). Ölçek geliştirme çalışmalarında kapsam geçerlik indekslerinin kullanılması[Use of scope validity indices in scale development studies]. XIV. National Educational Science Congress, (pp. 1-6). Denizli. 